\title{
大阪湾およびその周辺海域の干潟における窒素収支と動植物現存量
}

\author{
Nitrogen Budgets and Standing Crops of the Benthic Organism at \\ Tidal Flats in and near Osaka Bay
}

矢持 進 ${ }^{1}$

\section{Susumu YAMOCHI}

\begin{abstract}
Field investigations were conducted at two semi-natural and four artificial tidal flats in and near Osaka Bay to examine nitrogen budgets and standing crops of the benthic organism in high water temperature seasons of 2000 to 2006 . The net exchange of nitrogen markedly changed from a source to a sink within 2 or 3 years of construction due to the massive reproduction of benthic organisms at the young artificial tidal flat. In contrast, nitrogen was trapped at a rate of ca. $100 \mathrm{mgN} / \mathrm{m}^{2} /$ day at the matured artificial tidal flat where dissolved inorganic nitrogen was temporally incorporated into the biomass and was exported in the form of dissolved organic nitrogen. The semi-natural tidal flat yielded a large quantity of bivalves and its nitrogen budget was well balanced compared to the artificial ones.
\end{abstract}

\section{1.はじめに}

水域環境の再生や親水空閒の創出を目標に，全国各地 の海岸で人工干潟や人工塩性湿地の造成が行われている. 干潟は水質浄化機能や生物保育機能に富むと言われてお ク，人為的に創出された干潟でもこれらの機能が創生さ れるとの報告がある（今村，1998）。このような背景の もと, 近年, 海岸工学分野においても人工干潟の機能と 構造に関する調查・研究が活発に行われるようになった (桑江ら，2003；国分ら，2005).しかしながら，複数の 干潟の水質浄化能と生物保育能を同じ研究チームが継続 的かつ定量的に調查し, 経年的な変動と空間的な差異を 比較・検討した事例は少ない. 本研究は, 大阪湾および その周辺海域に存在または造成された半自然干潟と人工 干潟を対象に, 形態別の爫素収支と優占動植物相を調査 し，そのデータの整理・解析を通じて人工干潟の造成に おいて目指すべき方向性を考察することを目的とした。

\section{2. 調査の方法}

\section{(1) 調 查海域}

2000 年から 2006 年の高水温期を中心に, 大阪市大阪 南港野鳥園北池, 大阪南港野鳥園南池, 岸和田市阪南 2 区人工干潟現地実験場，岸和田市阪南 2 区干潟創造実験 場, 和歌山市和歌川河口干潟，ならびに和歌山県田辺市 内之浦干潟の計 6 力所で観測を実施した（表-1, 図-1).

大阪南港野鳥園は 1983 年に造成された塩性湿地で, 大阪湾に面する湿地北西側は消波プロックやコンクリー トケーソンで囲まれているため，波浪の影響が殆どなく 潟湖的特街を有している。この人工塩性湿地は北池・西 池・南池から構成されるが，このうち北池 (面積約 4.0 ha) は，1995 年に鋼管 6 本が敷設され，湿地内に海水が

1 正 会 員 農博 大阪市立大学教授大学院工学研究科都市系専攻

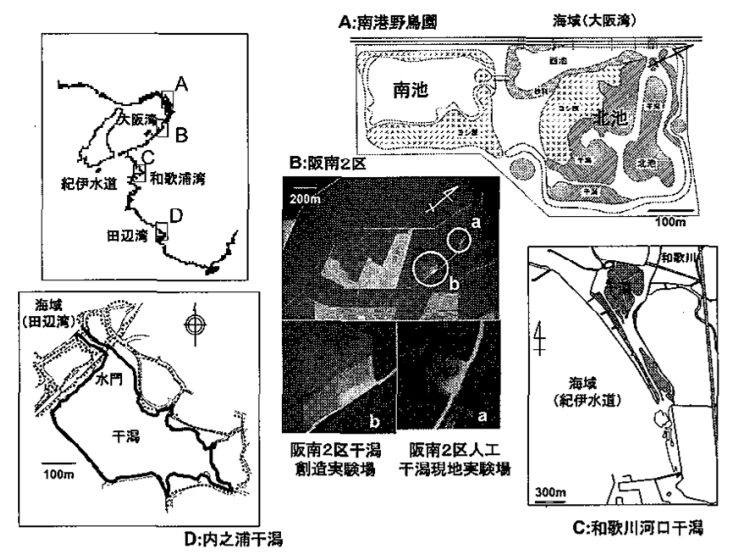

図-1 調查対象干潟

表-1 調査対象干潟の諸元

\begin{tabular}{|c|c|c|c|c|}
\hline 対象干潟 & 場 所 & 種 類 & $\begin{array}{l}\text { 面皘 } \\
\text { (ha) }\end{array}$ & 造成年 \\
\hline $\begin{array}{r}\text { 大阪南港野鳥園 } \\
\text { 北池 }\end{array}$ & 大阪市 & 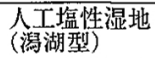 & 4.0 & 1983 年 \\
\hline $\begin{array}{c}\text { 大阪南港野島園 } \\
\text { 南池 }\end{array}$ & 大阪市 & $\begin{array}{l}\text { 人工塩性湿地 } \\
\text { (潟湖型) }\end{array}$ & 3.8 & 1983 年 \\
\hline 阪南 2 区人工干潟 & 大阪府岸和田市 & $\begin{array}{l}\text { 人工干潟 } \\
\text { (前浜型) }\end{array}$ & 0.8 & 2000 年 \\
\hline $\begin{array}{r}\text { 阪南 } 2 \text { 区干潟凔造 } \\
\text { 実験場 }\end{array}$ & 大阪府岸和田市 & $\begin{array}{l}\text { 人工干潟 } \\
\text { (前浜型) }\end{array}$ & 5.4 & 2004 年 \\
\hline 和歌川河口干潟 & 和歌山市 & $\begin{array}{l}\text { 半白然干潟 } \\
\text { (河口型) }\end{array}$ & 55 & \\
\hline 内之浦千潟 & 和歌山県田辺市 & $\begin{array}{l}\text { 半自然干潟 } \\
\text { (溜湖型 }\end{array}$ & 5.6 & \\
\hline
\end{tabular}

流入するようになった。この海水導入管の下端の地盤高 は D.L.+0.15 m で，大潮や中潮の干潮時には湿地の多 くが干出する特徵がある。 また，南池（面積約 3.8 ha） にも2004 年 5 月にポリエチレン管 2 本が設置され, 海 水の導入が行われたが, 管底の位置が D.L. $+0.60 \mathrm{~m}$ と 北池より高いため干潮時にも冠水する面積が比較的大き い. 雨池とも湿地造成材料として浚渫土が用いられ, 棇 渫土の上に海砂が $40 \mathrm{~cm}$ の厚みで敷き詰められた。な お，現在は海砂の上に細粒分の堆積が認められる。 
岸和田市阪南 2 区人工干潟現地実験場（面積 $0.8 \mathrm{ha}$ ) は 2000 年 5 月に阪南 2 区整備事業に伴う環境保全代償 措置として埋め立て予定地内に試験的に造成された前浜 型の人工干潟である。本干潟の養浜材としては近隣の港 湾海域から採取した浚渫土が用いられており，干潟の面 積の $1 / 4$ には浚渫土の上に海砂が $1 \mathrm{~m}$ の厚みで敷き詰 められた。干潟の周囲は捨て石からなる土留め堤と側壁 ならびに石積み護岸で囲まれており，干潟勾配は $3 / 100$ から $5 / 100$ である. な押，本干潟は岸から約 $1 \mathrm{~km}$ の沖 合に位置し，近隣からの河川流入の直接的影響はない.

阪南 2 区干潟創造実験場は上記の人工干潟現地塞験場と 同じ埋め立て地に 2004 年 2 月に創出された面積約 5.4 ha の前浜型の人工干潟である.この干渴は沖合方向に 160-270 m, 幅 $260 \mathrm{~m}$ の長さがあり，岸側護岸から沖合 80 $\mathrm{m}$ には中仕切り堤が設置されている. 中仕切り堤の沖側 は DL. $-1.9 \mathrm{~m}$ から D.L. $-2.3 \mathrm{~m}$ で常に冠水する浅海域で あるのに対して中仕切り堤と岸側護岸の間は大潮干潮時に は多くが干出する，盖浜材には大阪湾北部港湾域の浚渫土 砂が使われ，中仕切り堤より岸側の干潟域（面積 $2.1 \mathrm{ha}$ ) の多くに打いて 0.3-1.2 $\mathrm{m}$ の厚さで覆砂が行われた.

和歌川河口干潟は面積が約 75 ha で，干潟奥部の底質 は泥質であるが残りは砂質を主成分とする半自然干潟で ある. 本干潟近隣に存在する河川としては和田川・和歌 川・津屋川があり，このうち和歌川河口部には河川水の 水質悪化を防ぐため 1979 年に和歌川排水機場が建設さ れ，干潟域の海水を $0-12 \mathrm{~m}^{3} / \mathrm{sec}$ の流量で河川上流方向 に転送している．また，津屋川の流量が極めて小さいこ とから，和歌川河口干潟に流入するのは主として和田川 の一部と紀三井寺川加らの河川水となる. 干潟勾配は奥 部で 2/100-8/100, 中部で 0.2/100-7/100, 外海との境 界付近で 0.3/100-12.5/100 とされている.

干潟面積約 5.6ha の田辺湾内之浦干潟では，19941998 年に親水公園化を目指して護岸のスロープ化・周 辺歩道の拡張・河川改修などの土木工事が行われた，そ のため，かつては入江であったものが堤防によって外海 と分離され, 現在は干潟北西部にある長さ $4 \mathrm{~m}$ の水門 2 箇所によって外海との海水交換が行われている，底質は 砂泥または泥質であり，大潮干潮時には殆ど干潟全域が 干出する．本潟湖的干潟には，3つの小河川が見られる が，降雨時を除き河川水流入量は極めて小さい。

なお，和歌川河口干潟や内之浦于潟の海底は人為的な 改変が加えられていないものの，周囲は石積み護岸やコ ンクリート護岸で覆われているため本研究においては両 干潟を半自然干潟と表現する.

(2) 観測方法

干潟の窒素収支については，干潟内外における栄養物 質濃度を 2 潮汋間調ベ，ボックスモデルによって求める
表-2 大阪湾およびその周辺海域の干潟における窒素収支

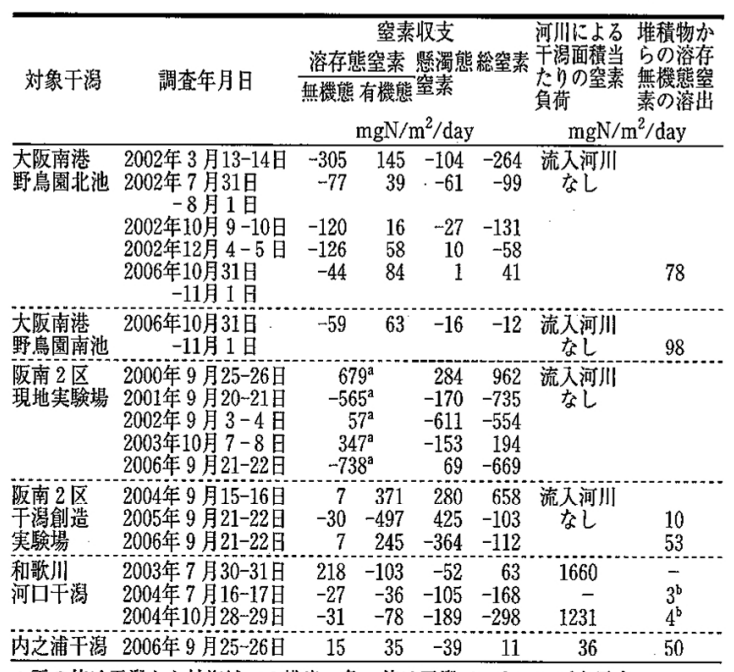

*正の值は干渴から外海域への排出、負の值は干舅でのトラッブを示す

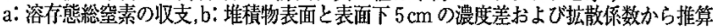

方法（松川，1989），または導水管，石積み護岸，水門， ならびに干潟一外海境界部での海水流入・流出量と栄盖 物質濃度を 1 洔間間隔で同じく 2 潮汐間にわたって測定 することによって算出する方法（矢持ら，2003）を用い た。 な抒，和歌川河口干潟と内之浦干潟では毎正時の河 川流量と河川水の窒素濃度から河川水による窒素負荷を 求めた。また，大阪南港野鳥園北池と南池，阪南 2 区干 潟創造実験場，和歌川河口干潟，ならびに内之浦干潟で はベンシックチャンバーまたはコアーサンプル管により 海底堆積物からの無機態窒素の溶出速度を測定した.

栄養物質動態に影響を及ぼす動植物については底生微 細藻頪, 海澡ならびに小型底生動物の現存量を調べた。 この場合，底生微細藻類現存量は干潟の海底堆積物を内 径 $1.8 \mathrm{~cm}$, 長さ約 $10 \mathrm{~cm}$ のアクリルパイプを用いて採 取したのち，その表面から $0.5 \mathrm{~cm}$ 層までの堆積物試料 についてクロロフィル a 濃度を測定することによって求 めた．海藻現存量は 1 片 $50 \mathrm{~cm}$ の方形枠を用いて海藻 を採集し，その湿重量から単位面積あたりの現存量を算 出した。 また, 小型底生動物現存量は小型採泥器（採取 面積 $0.0225 \mathrm{~m}^{2}$ ) か港研式採泥器 (採取面積 $0.045 \mathrm{~m}^{2}$ ) で海底堆積物を採取した後 $1 \mathrm{~mm}$ 目の管にかけ，残存し た生物の湿重量を分類群別に測ることによって求めた.

\section{3. 結果}

\section{（1）窒素収支}

大阪湾㧍よびその周辺海域に存在する 6 筫所の干潟の 窒素収支を表-2に示す。大阪南港野鳥園北池での総空 素の収支については，2006 年 10 月 31 日 - 11 月 1 日の 観測時を除き，北池は $-58 \mathrm{mg} / \mathrm{m}^{2} /$ day から -264 $\mathrm{mg} / \mathrm{m}^{2} /$ day の值を示し, 窒素としては干潟内にトラッ 
プされている状況が窺われた，形態別に見ると，有機態 窒素は $16 \mathrm{mg} / \mathrm{m}^{2} /$ day から $145 \mathrm{mg} / \mathrm{m}^{2} /$ day の範囲内で 大阪湾へ排出されていたのに対して無機態窒素は 44 $\mathrm{mg} / \mathrm{m}^{2} /$ day 加ら $305 \mathrm{mg} / \mathrm{m}^{2} /$ day (平均 $134 \mathrm{mg} / \mathrm{m}^{2}$ /day）の範团で大阪湾から取り込んでいた。な押，懸 濁態窒素には一定の傾向が見られなかった．結果的に北 池は外海から無機態窒素を取り込み，それを有機態窒素 に変換して排出し, 総体としてみると窒素を干潟内にト ラップする機能があることがわかった.このことと, 堆 積物から水中へ溶存態窒素が $78 \mathrm{mg} / \mathrm{m}^{2} /$ day の速度で 溶出していることを考えると, 冠水時の干潟における溶 存態窒素のトラップ速度は $200 \mathrm{mg} / \mathrm{m}^{2} / \mathrm{day}$ 前後に達す るのかも知れない。大阪南港野鳥園北池に隣接し; 冠水 面積は北池より広いが，海水導入が図られて 2.5 年しか 経過していない南池でも窒素収支について同様の現象が 見られた。すなわち, 無機態窒素を取り込み, 有機態窒 素に形態を変化させて海域に放出するが, 総窒素で見る と流入量より流出量が少なかった. 堆積物からの溶存態 窒素の溶出速度は北池と同程度の $98 \mathrm{mg} / \mathrm{m}^{2} /$ day であ った. 基本的に大阪南港野鳥園北池と南池は窒素を干潟 内にトラップする Sink タイプの干潟であると言える.

大阪南港野鳥園ほど富栄養化していない大阪岸和田阪 南 2 区人工干潟現地実験場では，9月末から 10 月初めの 晚夏に観測を行ったが, 総窒素の収支は $962 \mathrm{mg} / \mathrm{m}^{2} /$ day から $-735 \mathrm{mg} / \mathrm{m}^{2} /$ day の間を大きく変動した，溶存態窒 素, 䣄濁態窒素, ならびに総窒素を見た場合, 值の絶対 值は $100 \mathrm{mg} / \mathrm{m}^{2} /$ day 以上を示すことが多く, 栄盖バラン スが安定せず，年によって干潟は窒素吸収の場になった り，外海への負荷源になったりすることがわかった。

阪南 2 区干潟創造実験場は阪南 2 区人工干潟現地実験場 の 6 倍の面積を有している.この干潟において, 同じ手法 により 3 か年連続して収支を調べた。総空素で見ると，造 成初年は干潟外への $658 \mathrm{mg} / \mathrm{m}^{2} /$ day の放出, 2 年目と 3 年目は約 $100 \mathrm{mg} / \mathrm{m}^{2} / \mathrm{day}$ の干潟内でのトラップという結 果が得られた，また，この干潟では窒素収支にお拧溶存 有機態窒素の寄与が大きかった. 経年的な変化を阪南 2 区 人工干潟現地実験場と比べると，造成初年は大幅な窒素の 排出であったものが次第に窒素固定の場へと変化するとい う共通点が認められた．この造成初年における干潟から外 海への窒素の排出については，浚渫土砂間隙水に含まれる 窒素の水中への溶出に一因すると考えられる. なお，溶存 態と懸濁態窒素それぞれの収支の変遷に関しては，3-6 年 経過しても一定の傾向が見られず，值は総じて大きいもの の不安定であった。 また, 海底堆積物からの溶存態無機窒 素の溶出速度は 2005 年 9 月が $10 \mathrm{mg} / \mathrm{m}^{2} / \mathrm{day}, 2006$ 年 9 月が $53 \mathrm{mg} / \mathrm{m}^{2} / \mathrm{day}$ であった.

和歌川河口干潟は和田川などからの污濁水の流入によ
表-3 大阪湾およびその周辺海域の干潟における藻類と 小型底生動物現存量

\begin{tabular}{|c|c|c|c|c|}
\hline 対象于潟 & 調査年月日 & $\begin{array}{l}\text { 海澡現存量 } \\
\mathrm{g} \text { wet } / \mathrm{m}^{2}\end{array}$ & 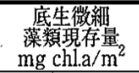 & $\begin{array}{l}\text { 少型底告 } \\
\text { 動物現量 } \\
\mathrm{g} \mathrm{wet} / \mathrm{m}{ }^{2}\end{array}$ \\
\hline $\begin{array}{l}\text { 太阪南港 } \\
\text { 野鳥園北池 }\end{array}$ & $\begin{array}{l}2000 \text { 年9月13日 } \\
2002 \text { 年10月9 } \\
2005 \text { 年10月18 } \\
2006 \text { 年6月14日 } \\
2006 \text { 年 7月26日 } \\
2006 \text { 年 } 8 \text { 月 } 23 \text { 日 } \\
2006 \text { 年11月1日 }\end{array}$ & $\begin{array}{r}0-5200(2628) \\
55-1545(433) \\
800-5720(2572) \\
380-4880(1780) \\
0-4140(1765) \\
480-8060(2289)\end{array}$ & $\begin{array}{r}29.7-256(100) \\
17-417(72) \\
37-698(194) \\
24-620(143) \\
17-239(120)\end{array}$ & $0-18(5.1)$ \\
\hline $\begin{array}{l}\text { 天绦南港 } \\
\text { 野鳥溒池 }\end{array}$ & $\begin{array}{l}2005 \text { 年10月18日 } \\
2006 \text { 年 6月14日 } \\
2006 \text { 年7 } 26 \text { 日 } \\
2006 \text { 年8 } 8 \text { 月 } 23 \text { 日 } \\
2006 \text { 年11月1 }\end{array}$ & $\begin{array}{r}85-6500(2275) \\
200-9680(3599) \\
0-4980(1529) \\
0-2640(690) \\
200-5160(1979)\end{array}$ & $\begin{array}{l}21-401(128) \\
16-233(91) \\
57-448(172) \\
33-401(131)\end{array}$ & $53-132(92)$ \\
\hline $\begin{array}{l}\text { 陑2干渴 } \\
\text { 人現地実験場 }\end{array}$ & 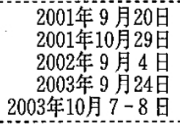 & $\begin{array}{l}0-10420(1160) \\
0-9560(1261) \\
0-1260(502)\end{array}$ & $\begin{array}{r}1.6-18.1(7.1) \\
0.03-166(39) \\
7.8-11.6(9.7)\end{array}$ & $\begin{array}{l}0-1833(313) \\
0-4727(441) \\
0-5760(930)\end{array}$ \\
\hline 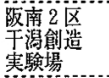 & $\begin{array}{l}2004 \text { 年 } 9 \text { 月 } 16-17 日 \\
2005 \text { 年 } 9 \text { 月 } 21-22 \text { 日 } \\
2006 \text { 年 } 9 \text { 月21-22日 }\end{array}$ & $\begin{array}{r}0-2520(858)^{\mathrm{a}} \\
40-4200(1729)^{\mathrm{a}} \\
0-4360(1498)^{\mathrm{a}}\end{array}$ & $1.6-10.7(4.4)$ & $0-637(195)$ \\
\hline 河口干渴 & 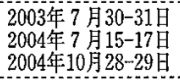 & $\begin{array}{r}0-6400(257) \\
0-4000(58) \\
0-1880(5)\end{array}$ & $\begin{array}{r}13.1-83.5(46) \\
15.9-116(53)\end{array}$ & $\begin{array}{r}95-1435(914) \\
354-4858(1949) \\
150-5718(1894)\end{array}$ \\
\hline 芮之浦干㵋 & 2006年9 月25-26日 & & $28.9-45.3(36)$ & \\
\hline
\end{tabular}

り, 夏季に干潟 $1 \mathrm{~m}^{2}$ 当たり1日 1200-1600 $\mathrm{mg}$ の窒素負荷 があることがわかった. 本河口干潟では懸濁態窒素と溶 存態有機窒素の収支が 3 回の調查とも負の值を示し(紜濁 態窒素: $-52 \mathrm{mg} / \mathrm{m}^{2} /$ day 加 $-189 \mathrm{mg} / \mathrm{m}^{2} /$ day, 溶存 有機態窒素: $-36 \mathrm{mg} / \mathrm{m}^{2} /$ day から $-103 \mathrm{mg} / \mathrm{m}^{2} /$ day), 流入水中の有機㲘濁物質や溶存有機物質が干潟内に残留 している間に海水中から消失していることが示唆された. 和歌川河口干潟では，干潟と外海境界部での総窒素の収 支は 3 回の観測のうち負の值が 2 回得られ, 見かけ上干 潟内で窒素がトラップされているという結果となった。 な押，正の值を示した 2003 年 7 月も $63 \mathrm{mg} / \mathrm{m}^{2} / \mathrm{day}$ と， 収支は比較的均衡がとれていた。本河口干潟の底質の多 くは砂質であるためか, 堆積物からの溶存態無機窒素の 溶出は少ないと考えられた $\left(3-4 \mathrm{mg} / \mathrm{m}^{2} / \mathrm{day}\right)$.

潟湖的特性を有する半自然干潟である田辺湾内の浦干 潟は, 底質の細粒成分が多いためか堆積物からの無機態 窒素の溶出速度か5 $50 \mathrm{mg} / \mathrm{m}^{2} /$ day と, 和歌川河口干潟 の 13-17 倍, 南港野鳥園や阪南 2 区干潟創造実験場のそ れと同じオーダーであった. また, 本干潟の周辺地域に は大規模な污濁負荷源がないため, 河川による干潟面積 当たりの空素負荷は和歌川河口干潟の 1/34 から 1/46で あった.この干潟の窒素収支については, 溶存態無機窒 素と溶存態有機窒素がそれぞれ $15 \mathrm{mg} / \mathrm{m}^{2} /$ day 35 $\mathrm{mg} / \mathrm{m}^{2} /$ day の外海への排出, 懸濁態窒素が $39 \mathrm{mg} / \mathrm{m}^{2}$ /dayの干潟での吸収となり, 結果的に総窒素としては $11 \mathrm{mg} / \mathrm{m}^{2} /$ day の放出となった. 面積 $56000 \mathrm{~m}^{2}$ の内の 浦十潟では, 1 日に家庭排水などにより約 $2000 \mathrm{~g}$, 海底 堆積物から約 $2800 \mathrm{~g}$ の窒素負荷があり, その約 $7 / 8$ は 干潟内でのトラップか脱窒などによる系外転送が行われ， 
残り $1 / 8$ にあたる約 $600 \mathrm{~g}$ の窒素を田辺湾へ栄養として 供給していることがわかった.

\section{（2）藻類と小型底生動物現存量}

表-3 に大阪湾およびその周辺海域の干潟における海藻, 底生微細藻類, そして小型底生動物の現存量を示す. 高水 温期の南港野鳥園北池ではアナアオサが, 南池では主とし てジュズモ属の 1 種が大量增殖し, 各調査時の平均湿重量 は, 北池で 433-2628 gwet $/ \mathrm{m}^{2}$, 南池で 690-3599 gwet $/ \mathrm{m}^{2}$ に達した.また, 両池では底生微細藻類も活発に增殖し, 多くの定点で $100 \mathrm{mg} \mathrm{chla} / \mathrm{m}^{2}$ を回る值となった. 小型 底生動物については 2000 年 9 月と 2006 年 6 月に調查した が, 現存量は 2000 年 9 月の北池で $0-18 \mathrm{gwet} / \mathrm{m}^{2}$, 同じく 2006 年 6 月の北池で 26-141 gwet $/ \mathrm{m}^{2}$ となった。この時の 個体数優占動物は 2000 年 9 月がドロクダムシ科, 2006 年 6 月が多毛類イトゴカイ科の 1 種 (Capitellidae sp.) と端脚類 ヨコエビ科(Corophium spp.)であった. また, 南池では 2006 年 6 月に多毛類イトゴカイ科または端朋類ヨコエビ 科がそれぞれ優占し， 53-132 gwet $/ \mathrm{m}^{2}$ の現存量を示した。

阪南 2 区人工干潟現地実験場では造成翌年からアオサ 類の大量增殖が認められ，2001 年 10 月と 2002 年 9 月 の現存量は最大で $1 \mathrm{~m}^{2}$ あり湿重 $10 \mathrm{~kg}$ 前後に及んだ. このような場合, アオサ類が 4-5 枚重なって海底面上を 覆い, 水中光量の海底面での減衰は著しいと考えられた。 底生微細藻類の増殖は南港野鳥園と比べて不活発で, 平 均現存量は 7.1-39 mg chl.a/ $/ \mathrm{m}^{2}$ であった。

なお，底生微細藻類が $0.03 \mathrm{mg} \mathrm{chl} . \mathrm{a} / \mathrm{m}^{2}$ と, 極めて低 レベルであった定点が確認されたが，この地点は地盤高 が高く, 干出時間の長い場所であった。 小型底生動物の 平均現存量は 2001 年 9 月が $313 \mathrm{gwet} / \mathrm{m}^{2}$ は, 2002 年 9 月が $441 \mathrm{gwet} / \mathrm{m}^{2}, 2003$ 年 9 月が $930 \mathrm{gwet} / \mathrm{m}^{2}$ と経年 的に増加したが, これは 1 個体当たりの重量の小さい端 脚類ドロクダムシ科からイガイ科の二枚貝ホトトギスガ イに優占動物が変遷したことに一因する。

阪南 2 区干潟創造実験場の中仕切り堤より岸側の海域で はアオサ類の一種が繁茂し, 2004 年, 2005 年, 2006 年の 9 月 中下旬の平均海藻現存量は, それぞれ $858 \mathrm{gwet} / \mathrm{m}^{2}, 1729$ gwet $/ \mathrm{m}^{2}, 1498 \mathrm{gwet} / \mathrm{m}^{2}$ となった. 底生微細藻類の現存量 は2006 年 9 月 21-22 日に調べたが， 1.6-10.7 $\mathrm{mg} \mathrm{chla} / \mathrm{m}^{2}$ の籁囲を変化し, 阪南 2 区人工干潟現地実験場と同程度で, 南港野鳥園北池や南池に比べて小さかった. また, 個体数 に関する優占小型底生動物は 2004 年 9 月がホトトギスガ イ，2006 年 9 月が多毛類の Sigambra tentaculata であった. 2003 年と 2004 年の和歌川河口干潟では, アナアオサ の出現状況が大きく異なった. 即ち, 2003 年はアナア オサが比較的濃密に出現したのに対して，2004 年は分 布域が限られており，2004 年の現存量は 2003 年に比べ, 高分布域で $1 / 6$ ，干潟全域で $1 / 5$ に過ぎなかった。この
原因に関しては，2004 年は日本列島への台風の接近や 上陸が多く，これによる海底攪乱と干潟外への流出に起 因すると考えられる，底生微細藻類現存量は南港野鳥園 と阪南 2 区の両干潟の扮抢よそ中間の值を示した．小型 底生動物現存量は極めて高く，アサリ，オキシジミなど の二枚貝やウミニナ科やイボキサゴなどが生息したため 多くの地点で $1 \mathrm{~kg} \mathrm{wet} / \mathrm{m}^{2}$ を回る数值となった．和歌 川河口干潟ではこのように貝類の増殖が活発であった。 内之浦干潟の底生微細藻類現存量は $28.9 \mathrm{mg} \mathrm{chl} . \mathrm{a} / \mathrm{m}^{2}$ か ら $45.3 \mathrm{mg} \mathrm{chl.a} / \mathrm{m}^{2}$ の範囲を変動し，その平均現存量 $36 \mathrm{mg} \mathrm{chl} . \mathrm{a} / \mathrm{m}^{2}$ は和歌川河口干潟と同レベルであった。

\section{4. 考察}

前浜型の若い人工干潟である阪南 2 区人工干潟現地実 験場と同干潟創造実験場では，造成当初は外海に対する 窒素供給の場であったものが窒素を取り込む場へと $2-3$ 年で移行する共通点が認められた．雨干潟では共に主た る造成材料として近隣海域からの浚渫土砂が使用された こと，造成翌年からアオサ類の一種などの海藻類の大量 繁茂が認められるようになり，その後アサリやホトトギ スガイなどの二枚貝が大量に増殖したことが知られてい る.このことから，当初は海底堆積物から溶出した窒素 を捕捉するものが干潟上に存在せず，干潟外に流出して いたが，海藻類の光合成や二枚貝の摂食活動によって外 海から流入した窒素と堆積物から溶出した窒素が干潟内 でトラップされるようになったと考えられる，実際，優 占海藻の現存量と日間生長速度から 1 日当たりの藻類に よる溶存態窒素の取り込み量を，またアサリの現存量, 個体重量，濾水速度などから小型底生動物による懸濁態 窒素の摄取量を阪南 2 区人工干潟現地実験場についてそ れぞれ試算してみると，その合計はボックスモデルによ る干潟内での窒素消失量を上回った（矢持ら，2003）。 アサリの活動に関する潮汐依存性, 粪 ・偽粪の再獎濁, 代謝産物としての海藻の有機態窒素の排出などを無視し ているため，これら底生動植物による取り込みを過大評 価している面は否めないが，若い人工干潟の窒素収支に ついては優占海藻や貝類など生物の関与が特に大きいの であろう。一方，雨人工干潟での底生微細藻類の生息は， 同じ人工水域である南港野鳥園北池・南池，ならびに和 歌川河口や内之浦などの半自然干潟に比べて䝷弱であっ た。この原因として，風浪による底面攪乱に加えて阪南 2 区の干潟ではアオサ類が海底を数重に覆い被さるよう にして繁殖したため，海底面上に分布する底生微細藻類 は光制限の状況に追い込まれたためと推察される。ちな みに，風浪の影響を受けたものの過度にアオサ類が分布 しなかった和歌川河口干潟では，阪南 2 区の両干潟より 数倍, 底生微細藻類現存量が多かった. 
成熟した人工塩性湿地である南港野鳥園北池では外海 から無機態窒素を吸収し，有機態呿素に変換して排出す るものの, 総䘭素は干潟内にトラップされる傾向が強か った.この結果は, 導水管の敷設などの順応的な管理が 行われれば，人工的な塩性湿地であっても生態系機能が 造成後に保持されることを示している，ところで，窒素 が継続的にトラップされる干潟では, 系外転送がなけれ ばいずれ窒素過多の状況に陥ってしまう。この点に関し て, 系外除去機能の一つとして, 本人工塩性湿地で底質 の脱空速度を調べたところ，10-29 mg/ $\mathrm{m}^{2} /$ day と特に 高い值でなかった，一方，本湿地には年間数万羽のシギ， チドリが飛来し，底生動物を索䬣することから，野鳥に よる系外転送の重要性が推察される，なお，本人工塩性 湿地北池は干出するエリアと冠水するエリアが混在し, そのためかアナアオサが濃密に分布するにもかかわらず, 底生微細藻類の出現量が多くなったと考兄られる，底生 微細藻類は堆皘物食性の多毛類や甲殻類の主要な饂生物 であるとともに，藻類が再懸濁することによって，䀣濁 物食の多毛類や軟体類の餌になるとも考えられる。これ らの多毛類, 甲殼類, 軟体類は野鳥の主要䬳料となるこ とから, 本人工塩性湿地は富栄盖で底生微細藻類が多く, また人間の侵入を抑制していることを通じて，小型底生 動物, 野鳥などによる物質転送が円滑に進められている のではないかと推察される.

一方, 和歌川河口干潟や内之浦干潟のような半自然干 潟では総窒素の排出・吸収が若い人工干潟に比べて小さ く, 栄盖物質出入りの均衡がとれている状況が見られた。 特に和歌川河口干潟では河川による干潟面積あたりの窒 素負荷が大きいにもかかわらず総窒素の収支が比較的均 衡していた。この和歌川河口干潟では河口部に排水機場 が建設されており, 干潟奥部の海水を河川上流側に輸送 することによって, 河川由来の污濁水が干潟の広域に拡 散するのを防いでいる. 2003 年 7 月 30-31 日の調査に よれば，1日に約 $8.2 \times 10^{5} \mathrm{~m}^{3}$ の河口水を上流に転送し， 結果として河川からの窒素負荷の $80 \%$ 近くが干潟に流 入するのを抑制した，中規模都市において河川からの污 濁物質負荷量が增大する場合, 水域の環境容量を考慮し つつ，このような対策も海域環境の保全に有効かと考え られる、また,このような污濁負荷の人為的な管理によ って, 和歌川河口干潟では適度な底生微細藻類と二枚貝 類の増殖が認められた. 食物連鎖の起点であり, 上位栄 養階層への物質転送が円滑な底生微細藻類が適度な生物 密度で増殖し，それが貝類現存量の増加に繋がるような 干潟の創生が今後必要かと考えられる。

\section{5. まとめ}

2000 年から 2006 年にかけて, 大阪湾とその周辺海域
に存在する干潟で窒素収支と優占生物に関する野外調查 を実施し，その結果を整理・検討したところ以下のよう な知見が得られた。

(1) 前浜型の若い人工干潟である阪南 2 区の両干潟につ いて，造成当初は周辺海域への窒素負荷源であったが， 経年的に外海の空素を取り込む場へと移行する傾向が 窥われた。一方, 成熟した潟湖的人工塩性湿地である 大阪南港野鳥園では, 溶存態無機窒素を取り込み, 溶 存態有機窒素として排出する特徴があるものの, 北池 では約 $100 \mathrm{mg} / \mathrm{m}^{2} /$ day の速度で窒素を干潟内にトラ ップしていた.

(2)和歌川河口干潟や内之浦干潟のような半自然干潟で は総受素の収支が若い人工干潟に比べて小さく，栄盖 物質収支の均衡がとれている状況が見られた. 特に和 歌川河口干潟では河川による干潟面積あたりの絰素負 荷が大きいにもかかわらず総空素の収支が比較的均衡 しているが, これは河口部の排水機場によって下水処 理水などの污濁流入水が系外転送された勃果が大きい と推察された。

(3)生物動態については, 人工干潟で海藻類の繁殖が著 しく, 反対に小型底生動物現存量が半自然干潟より小 さかった，後者については主として貝類現存量の差異 に起因した. 底生微細藻類は若い人工干潟で現存量が 小さい傾向が認められた。

謝辞 : 本研究は, 大阪市立大学工学部または大学院工学 研究科に所属した楖川竜一氏, 岡本庄市氏, 宮本宏隆 氏, 田口敬祐氏, 田口恵美氏, 大西 徹氏, 松久純世 氏, 平井 研氏, 藤原俊介氏, 橘 美典氏, 那須陽平 氏, 小林愛実氏, 前畑友香氏, 清水広之氏, 神保幸代 氏らとともに行った研究活動の成果を取り継めたもの である．また，阪南 2 区干潟創造実験場の小型底生動 物データの一部は国交省国土技術政策総合研究所から 提供を受けた。ここに記して深謝いたします。

\section{参 考 文 献}

今村 均 (1998): 人工干潟造成の現状と課題, 沿岸の環境圈, フジ・テクノシステム, pp. 1112-1121.

桑江朝比呂・河合尚男・赤石正廣 - 山口良永 (2003): 三河湾の 造成干潟および自然干潟に飛来する鳥頑群集の観測とシ ギ・チドリ類が果たす役割, 海岸工学論文集, 第 50 巻, pp. 1256-1260.

国分秀樹·奥村宏征・上野成三・高山百合子・湯浅城之 (2005): 英梹湾に扔ける浚渫へドロを用いた大规模造成干 潟の底質と底生動物の特性について, 海岸工学論文集, 第 52 巻, pp. 1196-2000.

松川康夫(1989): 内湾域における物質輸送機構と窒素・隣の収 支と循環に関する研究, 中央水産研究所報告, 第 1 巻, pp. 1-74.

矢持 進・柳川竜一・橘 美典 (2003): 大阪南港野鳥園湿地に おける物質收支と水質浄化能の評価, 海岸工学論文集, 第 50 巻, pp. 1241-1245. 